\title{
GMR
}

\section{Genetic diversity of yacon accessions using ISSR markers}

\author{
R.M. Lorenzoni ${ }^{1}$, F. Menine ${ }^{2}$, E. Marques Júnior ${ }^{1}$, F.L. Oliveira ${ }^{2}$ and \\ T.C.B. Soares ${ }^{3}$ \\ ${ }^{1}$ Laboratório de Bioquímica e Biologia Molecular, \\ Departamento de Produção Vegetal, \\ Centro de Ciências agrárias e Engenharias, \\ Universidade Federal do Espírito Santo, Alegre, ES, Brasil \\ ${ }^{2}$ Departamento de Produção Vegetal, Centro de Ciências agrárias e Engenharias, \\ Universidade Federal do Espírito Santo, Alegre, ES, Brasil \\ ${ }^{3}$ Laboratório de Bioquímica e Biologia Molecular, \\ Departamento de Farmácia e Nutrição, Centro de Ciências Exatas, \\ Naturais e da Saúde, Universidade Federal do Espírito Santo, Alegre, ES, Brasil \\ Corresponding author: T.C.B. Soares \\ E-mail: tais.soares@ufes.br / tcbsoares@yahoo.com.br \\ Genet. Mol. Res. 16 (2): gmr16029576 \\ Received December 9, 2016 \\ Accepted March 2, 2017 \\ Published April 13, 2017 \\ DOI http://dx.doi.org/10.4238/gmr16029576
}

Copyright $(2017$ The Authors. This is an open-access article distributed under the terms of the Creative Commons Attribution ShareAlike (CC BY-SA) 4.0 License.

ABSTRACT. Yacon cultivation has been intensified and the
investigations of this crop have increased at the scientific, agricultural,
and social levels because the roots of yacon show beneficial properties
for human health, such as reducing cholesterol and glucose blood
levels. Since the investigations involving yacon are very recent, there
is little information available in terms of the genetic characterization
of the cultivated genotypes. In view of the lack of information on
the accessions cultivated in the State of Espírito Santo, Brazil, this
pioneering study aimed to characterize 60 accessions cultivated in the
state using ISSR yacon markers with emphasis on identifying the genetic
diversity among the materials. The 20 ISSR primers used produced a

Genetics and Molecular Research 16 (2): gmr16029576 
total of 82 fragments, $39.6 \%$ of which presented polymorphism. The number of fragments per primer ranged from 1 to 10 . The dissimilarity values ranged from 0 to 0.54 according to the Jaccard coefficient. A dendrogram was generated in which the accessions were divided into 3 groups; group 1 contained 58 individuals and groups 2 and 3 had only one individual in each group. The clustering of 58 accessions in a single group shows the low diversity in the materials examined. This low diversity indicates that new genotypes must be introduced in order to promote increased variability, which would minimize the adverse effects caused by biotic and abiotic factors.

Key words: Smallanthus sonchifolius; Molecular markers; Genetic variability

\section{INTRODUCTION}

Smallanthus sonchifolius (Poepp. and Endl.) H. Rob., also known as yacon, is a perennial species of Andean origin belonging to the Asteraceae family (Ojansivu et al., 2011). Due to its bioactive components, such as inulin-type fructan and fructooligosaccharides, which offer several health benefits, yacon has been considered a functional food (Gusso et al., 2015).

Recent studies have shown that nutritionally yacon offers several health benefits such as reduced cholesterol and glucose blood levels (Zaparolli et al., 2013), immunostimulatory properties (Vaz-Tostes et al., 2014), prebiotic effects (Campos et al., 2012), and protection against colon cancer (de Moura et al., 2012), among others.

As a consequence of these benefits, there has been an increase in interest in yacon worldwide, which has promoted greater consumption and aroused interest mainly in the food and pharmaceutical industries (Coll Aráoz et al., 2014; Gusso et al., 2015). This interest has opened new opportunities for the cultivation of yacon as a product that should be explored and applied at the social, agricultural, technological, and scientific levels.

Studies of yacon have been conducted in several countries, such as Korea, Ecuador, Japan, Peru, the Czech Republic, and the United States of America (Seminario et al., 2003; Fernandez et al., 2006) as well as in Brazil (Oliveira and Nishimoto, 2004; Silva, 2015). However, little information about the genetic diversity of the materials has been made available to date.

Because the diffusion of yacon is recent, it is urgently necessary to explore the cultivar and gain knowledge of the genetic material. It is known that members within the species have different chromosome numbers, with individuals containing $2 \mathrm{n}=30,2 \mathrm{n}=32,2 \mathrm{n}=58$, $2 \mathrm{n}=87$, and $2 \mathrm{n}=116$ chromosomes. Phenotypic variation in the color of the roots, such as yellow, white, yellowish-white, orange, and purple-yellow colors (Svobodová et al., 2013), has already been observed. These variations can cause changes in the quantity and quality of the tuberous roots produced, which directly interferes with the cultivation perspectives of the plant. This phenotypic variability of the roots allows for the production of different genotypes to meet the demands of different markets, mainly in terms of the phytonutrients found in each phenotypic variety. For example, the plants with purple roots present a greater amount of anthocyanins than the others, whereas the plants with yellow and orange roots present higher beta-carotene content.

Genetics and Molecular Research 16 (2): gmr16029576 
Due to the range of morphological characteristics and ploidy differences presented by the species, molecular studies are necessary to verify the genetic diversity of the genotypes, since these studies evaluate the individuals at the DNA level, which excludes the influence of environmental factors.

Some of the most efficient methodologies for studying diversity and genetic structure are those that use molecular markers. Among them, methods utilizing ISSR (inter-simple sequence repeat) markers (Zietkiewicz et al., 1994), which are effective in the detection of polymorphisms, are highly reproducible, do not require prior knowledge of the genome sequence, and present a low cost of analysis (Chagas et al., 2015). ISSRs have been successfully used in studies of genetic diversity, genetic mapping, germplasm identification, and fingerprint construction of different crops (Golkar et al., 2011).

In view of the above, this study aimed to estimate the genetic diversity of different accessions of yacon produced in the State of Espírito Santo, Brazil, to guide the development of public policies related to providing technical assistance to rural producers and helping research and extension agencies determine whether there is a need to introduce new cultivars, with an overall aim of expanding the cultivar in the state.

\section{MATERIAL AND METHODS}

\section{Plant material}

The accessions used in this study came from commercial crops (cultivated at an altitude of approximately $900 \mathrm{~m})$ in the municipalities of Domingos Martins $\left(20^{\circ} 16^{\prime} \mathrm{S}, 40^{\circ} 52^{\prime} \mathrm{W}\right)$ and Santa Maria de Jetibá $\left(20^{\circ} 05^{\prime} \mathrm{S}, 40^{\circ} 48^{\prime} \mathrm{W}\right)$, which is a mountainous region of the State of Espírito Santo. The collection was carried out at 12 rural properties and five accessions per area were sampled, which generated a total of 60 accessions.

\section{DNA extraction}

The molecular analyses were performed at the Laboratory of Biochemistry and Molecular Biology of the Center of Agrarian Sciences and Engineering of the Federal University of Espírito Santo (CCAE-UFES). For the genomic DNA extraction, young, completely expanded, and healthy leaves were collected. The DNA extraction was performed according to methods described by Doyle and Doyle (1990). After extraction, the samples were analyzed using the Nanodrop ${ }^{\circledR}$ (Thermo Scientific, Waltham, MA, USA) to verify the quantity and quality of the obtained DNA.

\section{ISSR analysis}

A total of 20 ISSR primers were used (Table 1). The amplification reactions were performed on PCR plates at a final volume of $20 \mu \mathrm{L}$ per sample in a mixture containing $30 \mathrm{ng}$ DNA; $0.25 \mu \mathrm{M}$ of each dNTP; $0.2 \mathrm{mM}$ primer; $10 \mathrm{mM}$ Tris- $\mathrm{HCl}, \mathrm{pH} 8.5 ; 2.4 \mathrm{mM}$ $\mathrm{MgCl}_{2}$, and 0.2 U Taq DNA polymerase. PCR was performed on the Applied Biosystems Veriti $^{2 \mathrm{M}}$ thermocycler. The programm used for amplification of the fragments consisted of the following steps: denaturation at $94^{\circ} \mathrm{C}$ for $5 \mathrm{~min}$, followed by 35 cycles of $94^{\circ} \mathrm{C}$ for 45 $\mathrm{s}$ (denaturation), $52^{\circ} \mathrm{C}$ for $45 \mathrm{~s}$ (annealing) and $72^{\circ} \mathrm{C}$ for $90 \mathrm{~s}$ (extension), and then a final

Genetics and Molecular Research 16 (2): gmr16029576 
extension at $72^{\circ} \mathrm{C}$ for $7 \mathrm{~min}$, with cooling at $4{ }^{\circ} \mathrm{C}$. The amplification products were separated using $2.5 \%$ agarose gel electrophoresis $(100 \mathrm{~V}$ for $4 \mathrm{~h}$ ). The gel was stained with $0.25 \mu \mathrm{g} / \mathrm{mL}$ ethidium bromide and then exposed to ultraviolet light and photographed in a Bio-Rad ${ }^{\circledR} \mathrm{Gel}$ Doc XR photodocumentation system.

\section{Statistical analyses}

The results generated by the amplification of the fragments were scored based on the presence (1) or absence ( 0 ) of the amplicon bands, thus producing a binary matrix. Genetic dissimilarity was estimated based on the complement of the Jaccard index.

Genetic dissimilarity of the 60 accessions was assessed using a clustering analysis by UPGMA (unweighted pair-group method using arithmetic averages) and then a dendrogram was generated, where the cut-off point was estimated using the Mojema coefficient (1997), with a value of $\mathrm{k}=1.25$.

The cophenetic correlation coefficient (CCC) between the matrix of genetic dissimilarity and the matrix of cophenetic values was calculated to verify the clustering consistency. Finally, a bootstrap analysis was performed to verify the consistency of the dendrogram nodes.

All analyses were performed in the GENES program (Cruz, 2013).

\section{RESULTS}

Of the 20 primers evaluated for amplification potential in the 60 S. sonchifolius individuals, 14 showed clear and well-defined bands that could be evaluated, whereas the other primers did not amplify.

A total of 82 fragments were produced, and the number of bands per primer varied from 1 (UBC 843) to 10 (UBC 840) (Table 1). Of the total fragments obtained, 39.6\% presented polymorphism.

Table 1. ISSR markers used to amplify Smallanthus sonchifolius, with the respective number of alleles, number of polymorphic alleles and \% of polymorphism.

\begin{tabular}{l|l|c|c|c}
\hline Primer & Sequence & Total number of alleles & Number of polymorphic alleles & $\%$ Polymorphism \\
\hline UBC 807 & AGA GAG AGA GAG AGA GT & 7 & 0 & 0.0 \\
\hline UBC 808 & AGA GAG AGA GAG AGA GC & 4 & 0 & 0.0 \\
\hline UBC 810 & GAG AGA GAG AGA GAG AT & 8 & 0 & 0.0 \\
\hline UBC 811 & GAG AGA GAG AGA GAG AC & 9 & 5 & 100.0 \\
\hline UBC 812 & GAG AGA GAG AGA GAG AA & 9 & 0 & 55.0 \\
\hline UBC 813 & CTC TCT CTC TCT CTC TT & 6 & 1 & 0.0 \\
\hline UBC 814 & CTC TCT CTC TCT CTC TA & 5 & 2 & 50.0 \\
\hline UBC 815 & CTC TCT CTC TCT CTC TG & 4 & 3 & 100.0 \\
\hline UBC 818 & CAC ACA CAC ACA CAC AG & 3 & 2 & 50.0 \\
\hline UBC 824 & TCT CTC TCT CTC TCT CG & 4 & 0 & 80.0 \\
\hline UBC 840 & GAG AGA GAG AGA GAG AYT & 10 & 5 & 0.0 \\
\hline UBC 842 & AG AGA GAG AGA GAG AYT & 7 & 0 & 100.0 \\
\hline UBC 845 & CTC TCT CTC TCT CTC TRG & 5 & & 0.0 \\
\hline UBS 843 & CTC TCT CTC TCT CTC TRA & 1 & & 0 \\
\hline Total Average & & & & \\
\hline
\end{tabular}

$\mathrm{R}$ : adenine or guanine; Y: cytosine or thymine.

According to the information generated by the amplification and the Jaccard index matrix, it was possible to estimate the dissimilarity values between the studied accessions.

Genetics and Molecular Research 16 (2): gmr16029576 
The lowest dissimilarity value was found between the LK5 and RP5, the RP1 and RP2, and the LB5 and LK3 (0.0) individuals, and the highest dissimilarity value was found between the DK3 and LK1 (0.5417) individuals. The CCC was 0.85 , which confirms a good association between the binary and dissimilarity matrices.

The dissimilarity matrix was used to generate a dendrogram (Figure 1) in which it is possible to observe the relationships between the accessions. It was possible to verify the formation of 3 distinct groups, with a mean distance of 0.30 among them. In group 1, 58 accessions were found, whereas groups 2 and 3 were formed by only one individual each, namely LB3 and LK1, respectively. The consistency, as verified through the bootstrap analysis, presented a value of $100 \%$ in the bifurcation where the cut-off point was adopted.

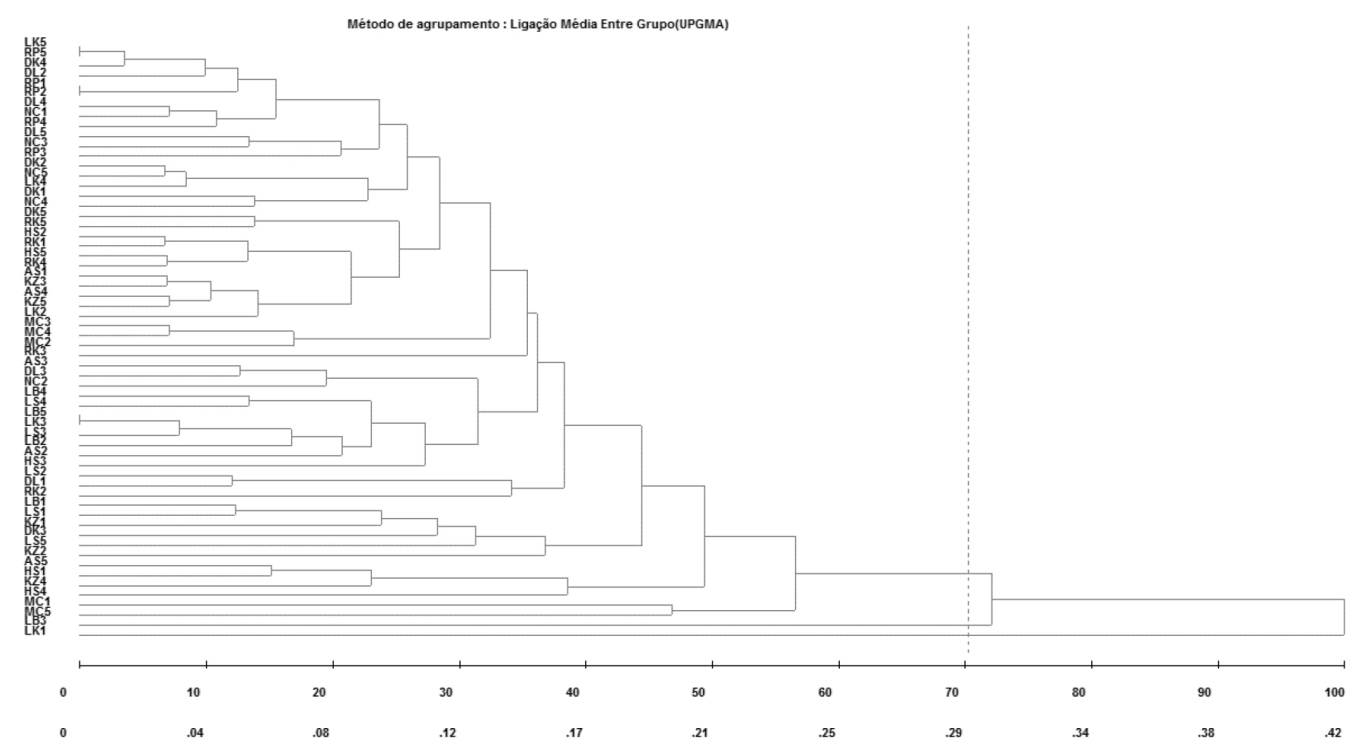

Figure 1. Dendrogram showing the genetic dissimilarity among the 60 accessions of Smallanthus sonchifolius, obtained using UPGMA and the complement of the Jaccard index as a measure of dissimilarity.

\section{DISCUSSION}

In species for which there are few studies, which is the case for yacon in Brazil, particularly in the State of Espírito Santo, it is necessary to gather a large amount of knowledge of the different genotypes in order to more efficiently manage the cultivation of the species. Performance-related morphological characters are easily influenced by environmental relationships, which may lead to erroneous observations of diversity in relation to the germplasm (Zhang et al., 2012). In contrast, molecular markers are not influenced by the environment and are highly informative, which makes them an effective alternative for this type of analysis.

Understanding genetic variability is fundamentally important for the development of strategies that aim to conserve the pool of genes that may express morphoagronomic characteristics of interest (Abdul Kareem et al., 2012). Therefore, in this study, the genetic

Genetics and Molecular Research 16 (2): gmr16029576 
diversity of yacon was verified for the first time in the State of Espírito Santo to understand the relationships between the accessions cultivated in the State. Of the total fragments generated using ISSR, only $39.6 \%$ presented polymorphism. However, the association between the observed low polymorphic level and the genetic dissimilarity values and cophenetic correlation coefficient confirmed that the ISSR markers used in this study were efficient in grouping the accessions.

A bootstrap analysis was effectively used to estimate the statistical support for the internal branches of the tree, where a value of $100 \%$ was found for the branches at the cut-off point. The branches of the groups that presented $70 \%$ support in the bootstrap analysis were considered to be consistent (Farsani et al., 2012). Thus, although some of the more basal branches had lower values, the definition of the formed groups was consistent.

The vast majority of the accessions were grouped into a single group (Figure 1), which indicates high similarity among the individuals. This result can be explained by the method of propagation in culture, which is mainly through clonal propagation. When evaluating the genetic diversity of pistachio, Kebour et al. (2012) found bootstrap values close to those observed in the present study, which they also related to the propagation method of the species.

The accessions LB3 and LK1 formed isolated groups, and these individuals were genotypically different in relation to the other accessions. This divergence may have been caused by mutation or the introduction of different materials into the growing area.

The percentage of polymorphism observed in this study is expected because although the genotypes studied are from different producers, the production of seedlings for planting occurs through the purchase and exchange of materials among the producers, which, according to technicians at the Capixaba Institute of Research, Technical Assistance and Rural Extension (INCAPER), means that the materials can have the same origin outside the state.

The genetic uniformity in the cultivated materials is a concern because it limits the ability of the farmers to explore the agronomic potential of the species. However, the species presents variability that should be explored. Svobodová et al. (2013) verified the genetic diversity of yacon plants obtained from different countries using ISSR markers and found $80.3 \%$ polymorphism. An association of these results with the cytogenetic and morphological data found by the same authors showed that there is evidence of diversity among yacon genotypes grown in different regions.

The lack of genetic diversity in the studied accessions suggests that attention should be given to searching for new genotypes to be introduced into this region because factors such as biotic and abiotic stresses may result in the inability to produce these materials in the various crop areas.

Promoting increased genetic variability by introducing new contrasting genotypes is fundamentally important to guarantee heterozygosity and thus increase the genotypes that are suitable for different adverse environmental conditions (Chapman et al., 2009).

\section{CONCLUSIONS}

There is low genetic diversity among the yacon accessions cultivated in Espírito Santo, Brazil. This low diversity suggests that different contrasting genotypes should be introduced to increase the variability among the materials in order to avoid the decimation of the yacon plant population through a pest or disease attack and/or through environmental changes.

Genetics and Molecular Research 16 (2): gmr16029576 


\title{
ACKNOWLEDGMENTS
}

\author{
Research supported by CNPq and FAPES. F.L. Oliveira was the recipient of a FAPES \\ research scholarship.
}

\section{REFERENCES}

Abdul Kareem VK, Rajasekharan PE, Ravish BS, Mini S, et al. (2012). Analysis of genetic diversity in Acorus calamus populations in South and North East India using ISSR markers. Biochem. Syst. Ecol. 40: 156-161. http://dx.doi. org/10.1016/j.bse.2011.09.012

Campos D, Betalleluz-Pallardel I, Chirinos R, Aguilar-Galvez A, et al. (2012). Prebiotic effects of yacon (Smallanthus sonchifolius Poepp. \& Endl), a source of fructooligosaccharides and phenolic compounds with antioxidant activity. Food Chem. 135: 1592-1599. http://dx.doi.org/10.1016/j.foodchem.2012.05.088

Chagas KPT, Souza RF, Fajardo CF and Vieira FA (2015). Seleção de marcadores ISSR e diversidade genética em uma população de Elaeis guineenses. Agraria 10: 147-152. http://dx.doi.org/10.5039/agraria.v10i1a5133

Chapman JR, Nakagawa S, Coltman DW, Slate J, et al. (2009). A quantitative review of heterozygosity-fitness correlations in animal populations. Mol. Ecol. 18: 2746-2765. http://dx.doi.org/10.1111/j.1365-294X.2009.04247.x

Coll Aráoz MV, Kortsarz González AM, Mercado MI, Ponessa GI, et al. (2014). Ontogeny and total sugar content of yacon tuberous roots and other three Smallanthus species (Heliantheae, Asteraceae), insights on the development of a semidomesticated crop. Genet. Resour. Crop Evol. 61: 163-172. http://dx.doi.org/10.1007/s10722-013-0022-0

Cruz CD (2013). GENES - a software package for analysis in experimental statistics and quantitative genetics. Acta Scientiarum 35: 271-276.

de Moura NA, Caetano BFR, Sivieri K, Urbano LH, et al. (2012). Protective effects of yacon (Smallanthus sonchifolius) intake on experimental colon carcinogenesis. Food Chem. Toxicol. 50: 2902-2910. http://dx.doi.org/10.1016/j. fct.2012.05.006

Doyle J and Doyle J (1990). Isolation of plant DNA from fresh tissue. Focus 12: 13-15.

Farsani TM, Etemadi N, Sayed-Tabatabaei BE and Talebi M (2012). Assessment of genetic diversity of Bermudagrass (Cynodon dactylon) using ISSR markers. Int. J. Mol. Sci. 13: 383-392. http://dx.doi.org/10.3390/ijms13010383

Fernandez EC, Viehmannova I, Lachman J and Milella L (2006). Yacon [Smallanthus sonchifolius (Poeppig \& Endlicher) H. Robinson]: a new crop in the Central Europe. Plant Soil Environ. 52: 564-570.

Golkar P, Arzani A and Rezaei AM (2011). Genetic variation in safflower (Carthamus tinctorious L.) for seed qualityrelated traits and inter-simple sequence repeat (ISSR) markers. Int. J. Mol. Sci. 12: 2664-2677. http://dx.doi. org/10.3390/ijms12042664

Gusso AP, Mattanna P and Richards N (2015). Yacon: benefícios à saúde e aplicações tecnológicas. Cienc. Rural 45: 912 919. http://dx.doi.org/10.1590/0103-8478cr20140963

Kebour D, Boutekrabt A and Mefti M (2012). Using ISSR markers to study genetic polymorphism of pistachio (Pistacia vera L.) in Algeria. E3 J Biotech and Pharma Res. 3: 47-53.

Ojansivu I, Ferreira CL and Salminen S (2011). Yacon, a new source of prebiotic oligosaccharides with a history of safe use. Trends Food Sci. Technol. 22: 40-46. http://dx.doi.org/10.1016/j.tifs.2010.11.005

Oliveira MA and Nishimoto EK (2004). Avaliação do desenvolvimento de plantas de yacon (Polymnia sonchifolia) e caracterização dos carboidratos de reservas em HPLC. Braz. J. Food. Technol. 7: 215-220.

Seminario J, Valderrama M and Manrique I (2003). El yacon: fundamentos para el aprovechamiento de un recurso promisorio. Lima, Peru: Centro Internacional de la Papa (CIP), Universidad Nacional de Cajamarca, Agencia Suiza para el Desarrollo y la Cooperación (COSUDE). 60.

Silva DMN. 2015. Cultivo de yacon em duas condições edafoclimáticas e épocas de plantio no sul do Espírito Santo. Universidade Federal do Espírito Santo, Alegre: CCAE/UFES. (Tese de Doutorado). 86.

Svobodová E, Dvoráková Z, Cepková PH, Viehmannová I, et al. (2013). Genetic diversity of yacon (Smallanthus sonchifolius (Poepp. e Endl.) H. Robinson) and its wild relatives as revealed by ISSR markers. Biochem. Syst. Ecol. 50: 383-389. http://dx.doi.org/10.1016/j.bse.2013.05.007

Vaz-Tostes Md, Viana ML, Grancieri M, Luz TCS, et al. (2014). Yacon effects in immune response and nutritional status of iron and zinc in preschool children. Nutrition 30: 666-672. http://dx.doi.org/10.1016/j.nut.2013.10.016

Zaparolli MR, do Nascimento NC, Baptista DR and Vayego AS (2013). Alimentos funcionais no manejo da diabetes mellitus. Rev. Ciênc. Saúde 6: 12-17. http://dx.doi.org/10.15448/1983-652X.2013.1.11471

Zhang F, Ge Y, Wang W, Yu X, et al. (2012). Molecular characterization of cultivated bromeliad accessions with Inter-

Genetics and Molecular Research 16 (2): gmr16029576 
Simple Sequence Repeat (ISSR) Markers. Int. J. Mol. Sci. 13: 6040-6052. http://dx.doi.org/10.3390/ijms13056040 Zietkiewicz E, Rafalski A and Labuda D (1994). Genome fingerprinting by simple sequence repeat (SSR)-anchored polymerase chain reaction amplification. Genomics 20: 176-183. http://dx.doi.org/10.1006/geno.1994.1151

Genetics and Molecular Research 16 (2): gmr16029576 